\title{
Archaeological Testing in the Devine Road Area North of Olmos Dam, San Antonio, Texas
}

Cristi A. Assad

Follow this and additional works at: https://scholarworks.sfasu.edu/ita

Part of the American Material Culture Commons, Archaeological Anthropology Commons, Environmental Studies Commons, Other American Studies Commons, Other Arts and Humanities Commons, Other History of Art, Architecture, and Archaeology Commons, and the United States History Commons

Tell us how this article helped you.

This Article is brought to you for free and open access by the Center for Regional Heritage Research at SFA ScholarWorks. It has been accepted for inclusion in Index of Texas Archaeology: Open Access Gray Literature from the Lone Star State by an authorized editor of SFA ScholarWorks. For more information, please contact cdsscholarworks@sfasu.edu. 


\section{Archaeological Testing in the Devine Road Area North of Olmos Dam, San}

Antonio, Texas

\section{Creative Commons License}

\section{(c) (1) (8)}

This work is licensed under a Creative Commons Attribution-NonCommercial 4.0 International License 


\section{ARCHAEOLOGICAL TESTING II THE

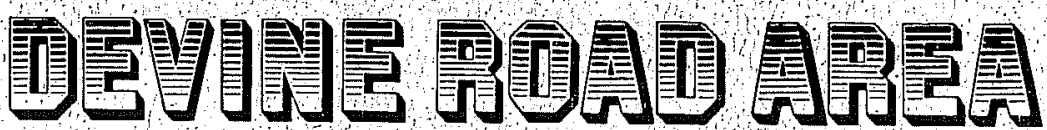 nORTH Of OLmos DAm, SAM AMTONIO, TEXAS}

\section{Cristi A. Assad}

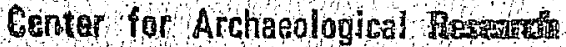

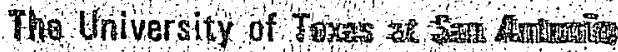

San Antanin, Tex J Th

Center for Archaeological Research

The University of Texas at San An tonio

Archaeological Survey Report, No. 53 


\section{ARCHAEOLOGICAL TESTING IN THE DEVINE ROAD AREA NORTH OF OLMOS DAM, SAN ANTONIO, TEXAS}

Center for Archaeological Research

The University of Texas at San Antonio

San Antonio, Texas 78285

Cristi A. Assad

Center for Archaeological Research

The University of Texas at San Antonio

Archaeological Survey Report, No. 53

1979 
List of Figures and Tables................. . i i Acknowledgments. . . . . . . . . . . . . . . . 1 i i Introduction ....................... 1 Previous Research .................... 1 Environment and Geology............... 3 History of the Area . . . . . . . . . . . . . . 3 Test Trenches .................. 3 $41 \mathrm{BX} 1 \ldots \ldots \ldots \ldots$ Site Description .................. 16 Site Investigation ................ 16 Lithic Artifacts . . . . . . . . . . . . 18 Other Artifacts ..................... 18 Radiocarbon Dating ................ 18 Summary and Recommendations ............... 21 References Cited ................... 22 Appendix ........................... 24 References Cited ................... . 24 


\section{LIST OF FIGURES AND TABLES}

Figure

Page

1. Location of $41 \mathrm{BX} 1 \ldots \ldots 2$

2. 01mos Dam Under Construction .......... 4

3. Site Map of $41 \mathrm{BX} 1$ and Vicinity .......... 5

4. Profile of Trench 2................. 7

5. Profile of Trench 3............... 8

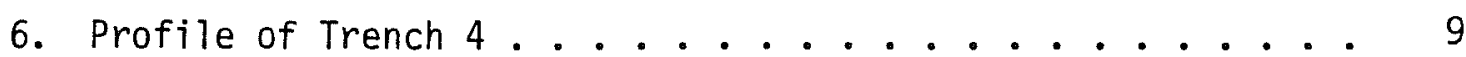

7. Profile of Trench 5, $41 \mathrm{BX} 1 \ldots \ldots$

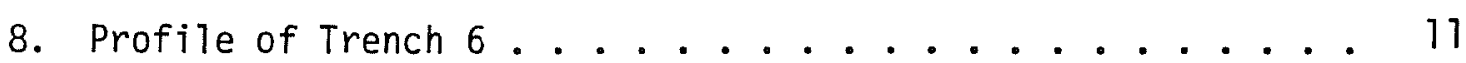

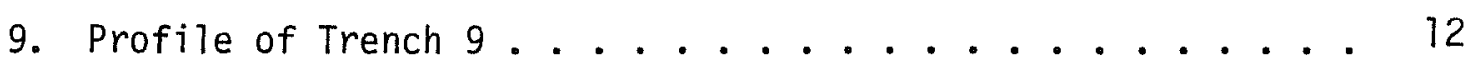

10. Profile of Trench $10 \ldots \ldots 13$

11. Profile of Trench $11 \ldots \ldots . . . \ldots 14$

12. $41 \mathrm{BX} 1$, Unit 1, 20-30 cm Level .......... 17

13. Artifacts from Unit 1 and the General Area ....... 19

14. Artifacts from $41 \mathrm{BX} 1 \ldots 25$

15. Artifacts from $41 \mathrm{BX} 1 \ldots . . . . . . . .26$

Table

1. Artifacts Recovered in Tests of Trenches 3,6, 9 and 10 .. 15

2. Artifacts Found in Unit 1 and Trench 5 ...... 20 


\section{ACKNOWLEDGMENTS}

Many people were instrumental in assisting the author with details for this project. Thanks to Mr. C. D. Orchard who took the time to visit the site and provide me with ideas and information. Mr. Brentano C. Harnish, Senior Vice President and Secretary of Pioneer Flour Mills, was gracious enough to allow the use of a photograph from the Pioneer Flour Mills 100th Anniversary publication; he also provided the specimens illustrated and described in the Appendix.

I would like to express my gratitude to Mr. Dorian French, Chief Engineer, and the backhoe crew from the San Antonio River Authority. Without their assistance our work would have been very difficult.

Many people from the Center for Archaeological Research have been very helpful. $\mathrm{Dr}$. Thomas R. Hester, Director, and Mr. Jack D. Eaton, Assistant Director, have provided guidance, suggestions and editing for this report. Thanks to Augustine Frkuska for preparing some of the report materials. 


\section{INTRODUCTION}

During late January and early February 1978, archaeological testing was carried out in an area north of 0lmos Dam, San Antonio, Texas (see Fig. 1) by personnel from the Center for Archaeological Research (CAR), The University of Texas at San Antonio. This work was performed under contract between CAR and the San Antonio River Authority.

The area tested consisted of 16 acres bounded by 01 mos Dam to the south, Devine Road to the west and 01mos Creek to the north and east. The objective of the testing was to determine whether any historic or prehistoric resources were present and, if so, to evaluate their significance prior to the use of the location as a borrow pit during the planned renovation of $01 \mathrm{mos}$ Dam.

During the construction of 01mos Dam in the 1920s, a prehistoric site, 41 BX 1 , was uncovered and mostly destroyed. Current testing in this area was designed to determine if any part of the site was left intact and to make recommendations for mitigation or protection.

The archaeological testing was performed under the supervision of Dr. Thomas $R$. Hester, Director and Mr. Jack D. Eaton, Assistant Director, of CAR. The field work was directed by Cristi Assad with the assistance of Augustine Frkuska, Rebekah Halpern and Robert F. Scott. All notes, maps and materials collected are on file at the Center for Archaeological Research.

\section{Previous Research}

Site 41 BX 1 was discovered during construction of 01 mos Dam in the 1920s. At that time interested persons collected a variety of artifacts, including PaleoIndian projectile points, Southwestern and local types of pottery, and faunal remains (some of extinct species).

Various authors have discussed site 41 BX 1. Woolford (1935), in a brief description of the site, made note of the "many examples of fine workmanship" of chert artifacts. Paleo-Indian projectile points and faunal remains from the vicinity of 41 BX 1 are reported by Orchard and Campbel1 (1954); in another publication by the same authors (1960), sherds of Southwestern pottery from the area are described. Other works providing information on 01mos Basin and Bexar County archaeology include those of Fawcett (1972), Fox (1975), Brown (1977) and Assad (1978).

Prior to the current project, the only controlled archaeological work performed at site 41 BX 1 was that testing carried out by Luke (1974). This initial testing, conducted by the Texas Highway Department, was restricted to the rightof-way of U.S. 281 (the McAllister Freeway). Extensive damage to the site was reported. The areas tested produced 1 ithic waste materials from the initial reduction stages. The right-of-way area tested by the Texas Highway Department is high above the flood plain of 01 mos Creek, and the depth of their test units indicated that the limestone walls of the valley were not very far below the ground surface. The current project deals with an area of the site which is much closer to the stream channel. 
This page has been

redacted because it

contains restricted

information. 
Environment and Geology

San Antonio has a relatively mild climate. There is precipitation throughout the year, heaviest in the spring and the fall (Taylor, Hailey and Richmond 1966). Thunderstorms can occur during any month and may cause localized flooding.

01 mos Creek has a drainage of approximately 30 square miles (Metcalf and Eddy 1920). The geologic deposits in the lower channel are alluvial sediments of Trinity and Frio soils (Taylor, Halley and Richmond 1966). These sediments are usually composed of organic material, clay, silt, sand and gravels. Detailed information about the soils encountered at site $41 \mathrm{BX} 1$ and vicinity is given in the Test Trenches section of this report.

In the area of the proposed borrow pit, the terrain has been extensively damaged and altered. There have been several floods in San Antonio's recorded history which have ravaged the 0lmos Basin, leaving behind reworked soils, organic materials, and building and other modern debris. The surface of the proposed borrow area is 1 ittered with bottles, metal cans and other such materials. Vegetation found in these stream valleys consists of elm, hackberry, pecan, oak and mesquite along with several types of tall grasses. Tall weeds and grasses extend from near the dam to the north and west for approximately 10 acres. Thereafter, pecan and other trees are gradually spaced, but within a short distance the trees are very young and closely spaced. The vegetation (during the winter months) is extremely dense throughout the area.

History of the Area

Several streams and springs are located in and around San Antonio. The largest of these streams is the San Antonio River. Runoff from the Edwards Plateau feeds the springs and streams, which fluctuate with the rainfall. 0lmos Creek flows southeasterly to join the San Antonio River at Incarnate Word College.

Several floods have scourged San Antonio since 1819 (Metcalf and Eddy 1920). It was after a disastrous flood in September 1921 that the City of San Antonjo decided to adopt the flood control plan that had been proposed by the consulting engineering firm of Metcalf and Eddy (status report by San Antonio River Authority 1970).

An unknown portion of site $41 \mathrm{BX} 1$ was destroyed by the construction of 01 mos Dam. Digging for the dam foundations extended to 40 feet in depth (see Fig.2), exposing the Paleo-Indian artifacts found by the several collectors (Orchard, personal communication). Some artifacts collected from the site by a local amateur archaeologist are discussed and illustrated in the Appendix.

\section{TEST TRENCHES}

Approximately 16 acres are to be used for the proposed borrow pit (see Fig. 3 for the boundaries), with four feet to be the approximate depth of the borrowing activities (Dorian French, personal communication). With the above information in mind, testing of the proposed borrow pit area was carried out. The San 

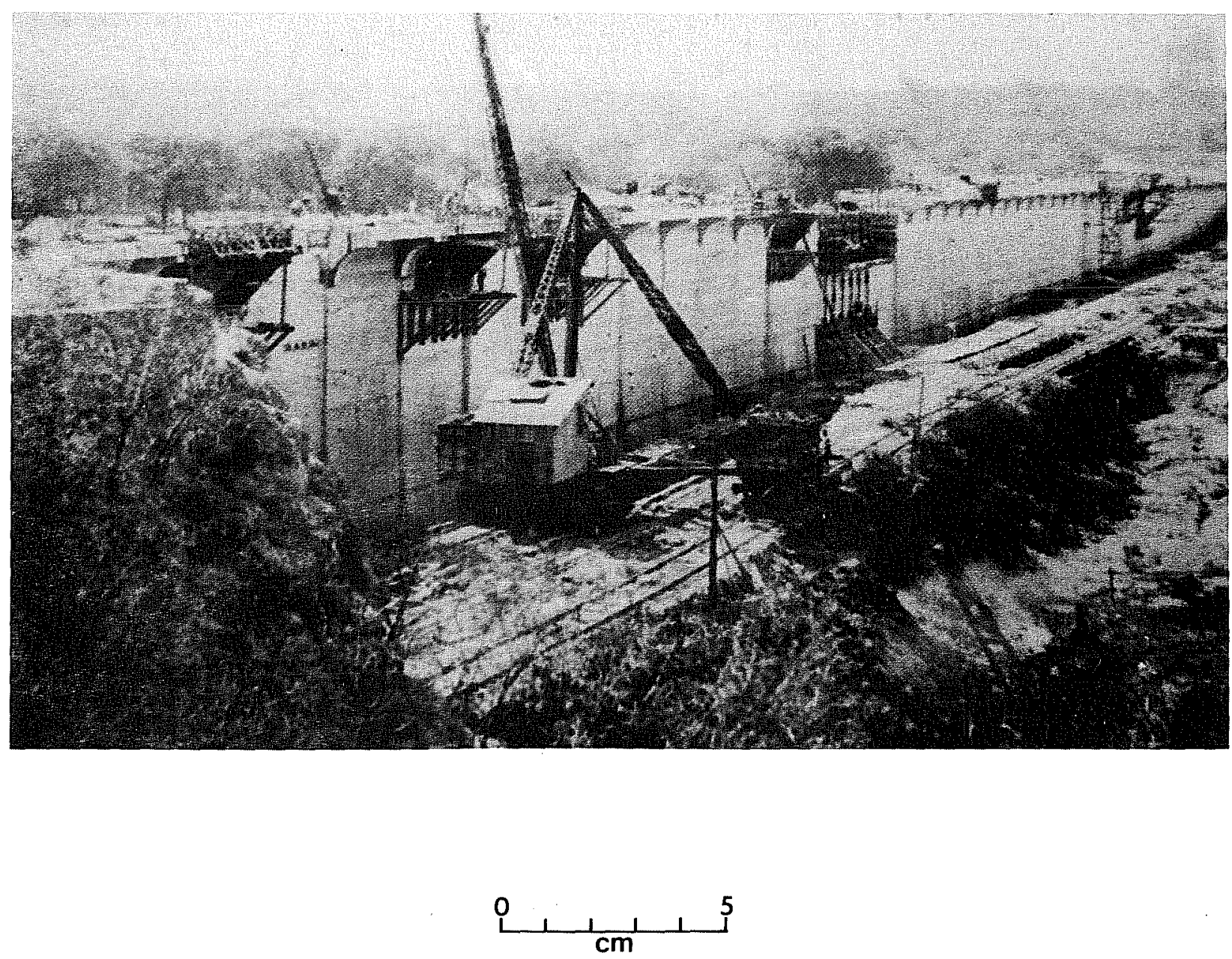

Figure 2. Oemos Dam Under Construction. This photograph is from 100 th Anniversary Pioneer Flour Mills, San Antonio, Texas 1851-1951. 
This page has been

redacted because it

contains restricted

information. 
Antonio River Authority provided the Center for Archaeological Research employees with a backhoe and operator for the digging of trenches.

A total of 13 test trenches were dug; their locations are shown in Fig. 3 . The placement of the trenches was biased, with the intent of getting as even a distribution as possible. Trenches 1, 2 and 3 were placed outside of the borrow pit area for the purpose of ascertaining the slope of the limestone valley wal1s. Limestone was located less than one meter deep in Trench 1 . Trench 2 was located less than $10 \mathrm{~m}$ away, but no 1 imestone was encountered in the deepest part of it, a depth of $2.8 \mathrm{~m}$. The depths and lengths of the trenches varied, but they were all excavated from 1.8 to $2.4 \mathrm{~m}$. All of the 13 test trenches were profiled, and eight of these are described in this section. The profiles are of Trenches 2,3,4,5,6,9, 10 and 11 . Trench 5 was cut into part of site 41 BX 1 prior to knowledge of its location. In an attempt to isolate the remains of the buried site, Trenches 3,6, 9 and 10 were dug. Each of these trenches was tested from below the disturbed zone by cutting out "levels" of $15 \mathrm{~cm}$ in a $50 \mathrm{~cm}$ wide by $10 \mathrm{~cm}$ deep cut along the trench wall that was profiled. Nothing of archaeological significance was uncovered in the testing. The few artifacts recovered are listed in Table 1.

The soil descriptions for the profiles were taken from the Rock-Color Chart distributed by the Geologic Society of America, Inc., 1975. The numerical terminology is that used in the Munsell System; the color names are from the Inter-Society Color Council--National Bureau of Standards (ISCC-NBS). In describing the attributes of the profiles, the detail was limited to a basic discussion of characteristics such as color, consolidation, texture and miscellaneous content (snail shells, rocks, etc.).

The "disturbed zone," the area where obvious soil mixing and non-native soils are located, is indicated by a heavy line in the profiles. The only two illustrated trenches that had no actual disturbed zone were Trenches 9 and 11 . The only visible disturbance of these two trenches was at the ground surface.

Much of the disturbed zone soils is probably a result of the construction activities when 01mos Dam was built and then covered by sediment build-up from later flooding. While the dam was being built, railroad tracks were installed on the north side of the structure to facilitate construction. The material in the disturbed zone of Trenches 2 and 3 (and possibly a few other trenches) most likely was fill which was dumped in the area to alleviate the swampy conditions present at the time (C. D. Orchard, personal communication).

The soils in the undisturbed zones of all the trenches are basically the same. The material is an alluvial deposit which may have been reworked from time to time. Once new sediments are deposited, there is little time for soil development; hence, soil horizons are indistinct (Taylor, Hailey and Richmond 1966).

A description of each trench which was profiled is presented along with the following profile drawings (Figs. 4-11). 
TRENCH 2

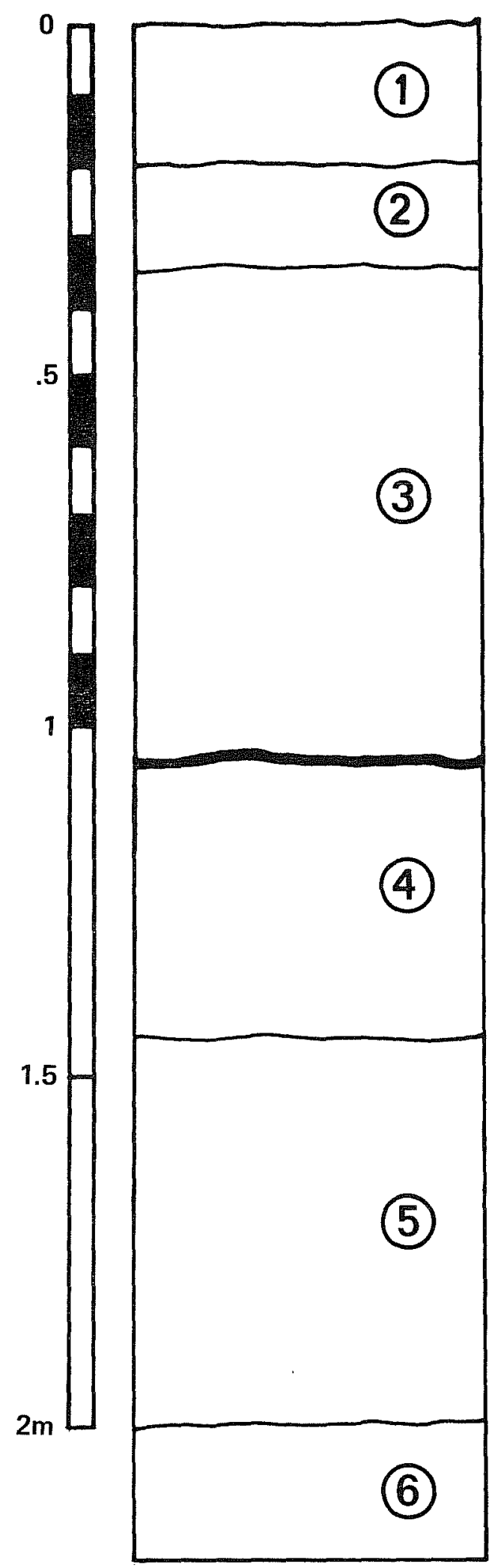

1 ground level-20 cm: Dusky yellowish brown (10YR2/2)

2 20-35 cm: Dark yellowish orange (10YR6/6) mixed with yellowish orange brown (10YR6/4)

$335-105 \mathrm{~cm}$ : Grayish orange (10YR7/4) mixed with pale yellowish orange (10YR8/6)

The soils from ground level to $105 \mathrm{~cm}$ are all part of the disturbed zone. The consolidation ranges from loose at the top to medium towards the bottom; soil texture is clayey and sticky when wet. Limestone pebbles are scattered throughout the $35-105 \mathrm{~cm}$ level.

4 105-145 cm: Moderate dusky brown (5YR2/4)

5 145-200 cm: Moderate light brown (5YR4/6)

$6200-280^{*} \mathrm{~cm}$ : Yellowish orange brown (10YR6/4) blended with moderate yellowish brown (10YR5/4)

The soils from $105 \mathrm{~cm}$ below ground level constitute the undisturbed zone. The soil color changes in all of the undisturbed zones grade into each other. Divisions were made where the change was most visible. The consolidation is soft to moderately hard; soil texture is silty clay and sticky when wet. Some land snail shells are found above $200 \mathrm{~cm}$, while limestone pebbles are to be found below $200 \mathrm{~cm}$. The soil is homogeneous in composition.

*The illustrated profile stops at $220 \mathrm{~cm}$.

Figure 4. Profile of Trench 2. 
TRENCH 3

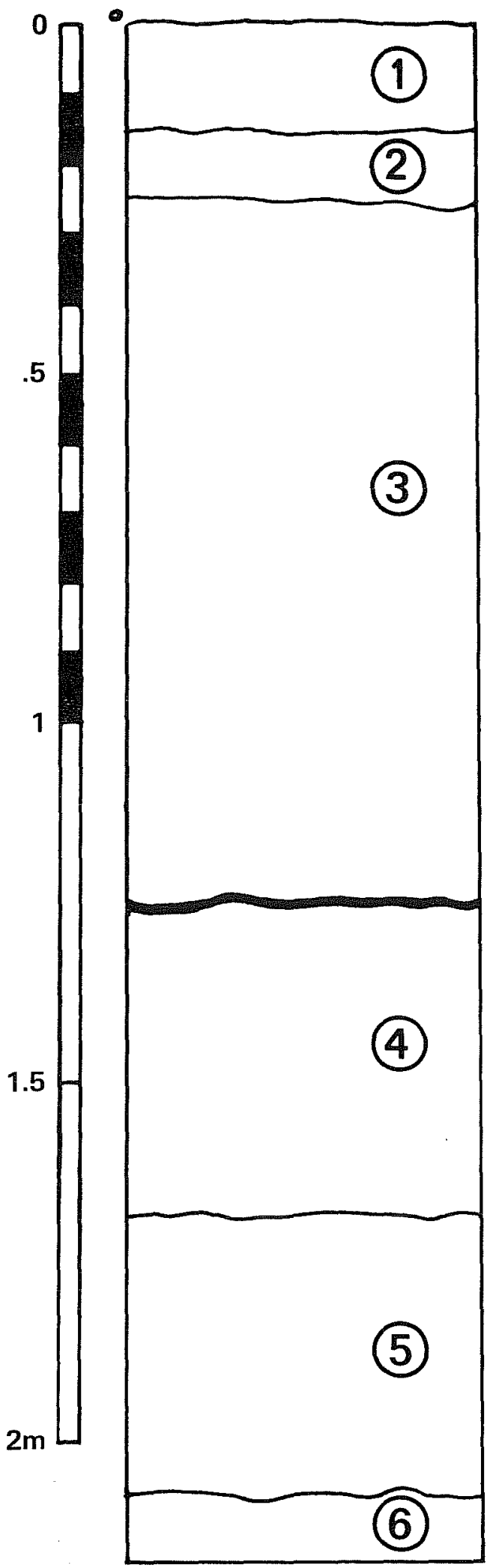

1 ground level-15 cm: Pale grayish brown (5YR4/2)

2 15-25 cm: Moderate yellowish brown (10YR5/4)

mixed with yellowish orange brown

(10YR5/6)

3 25-125 cm: Yellowish orange (10YR7/6)

The soils from ground level to $125 \mathrm{~cm}$ are all part of the disturbed zone. The consolidation is generally soft and loose. The soils range from a clayey loam at ground level to a calcareous clay. The materials in the $15-25 \mathrm{~cm}$ layer are very mixed.

4 125-170 cm: Dusky brown (5YR2/2)

5 170-210 cm: Yellowish brown (10YR3/2)

$6210-265^{*} \mathrm{~cm}$ : Dark yellowish brown (10YR4/2)

The soils from $125 \mathrm{~cm}$ below ground level constitute the undisturbed zone. The soil color change is gradual. Consolidation ranges from moderately soft to moderately hard. The soil is homogeneous in composition; the texture is clay. A few land snail shells and limestone pebbles are found throughout the zone.

A test column from $125 \mathrm{~cm}$ below ground surface to $215 \mathrm{~cm}$ below ground surface $(90 \mathrm{~cm})$ revealed no evidence of in situ archaeological remains.

*The illustrated profile stops at $220 \mathrm{~cm}$.

Figure 5. Profile of Trench 3 . 
TRENCH 4

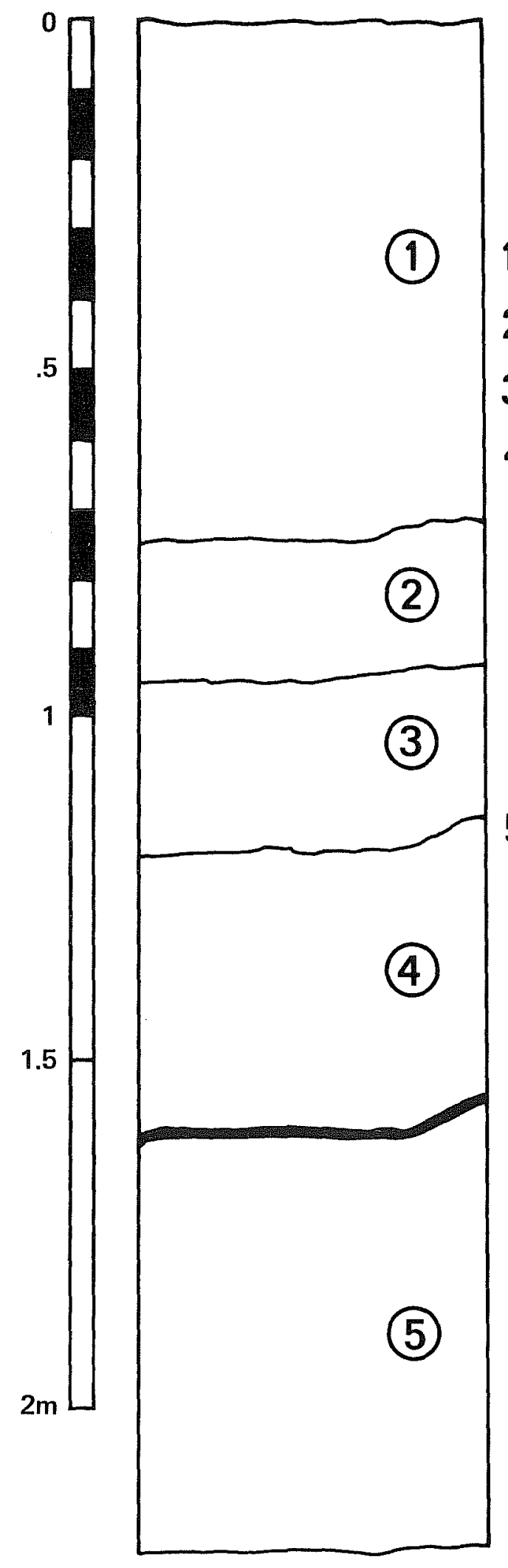

5 160-240** cm: Dusky yellowish brown (10YR2/2)

This stratigraphic level constitutes the undisturbed zone. There was no noticeable soil color change in this zone. The consolidation is moderately hard. Soil texture is a clay and silt mixture; the composition is homogeneous. Land snail shells are thinly scattered throughout.

* Approximate depth.

** The illustrated profile stops at $220 \mathrm{~cm}$. 
TRENCH 5

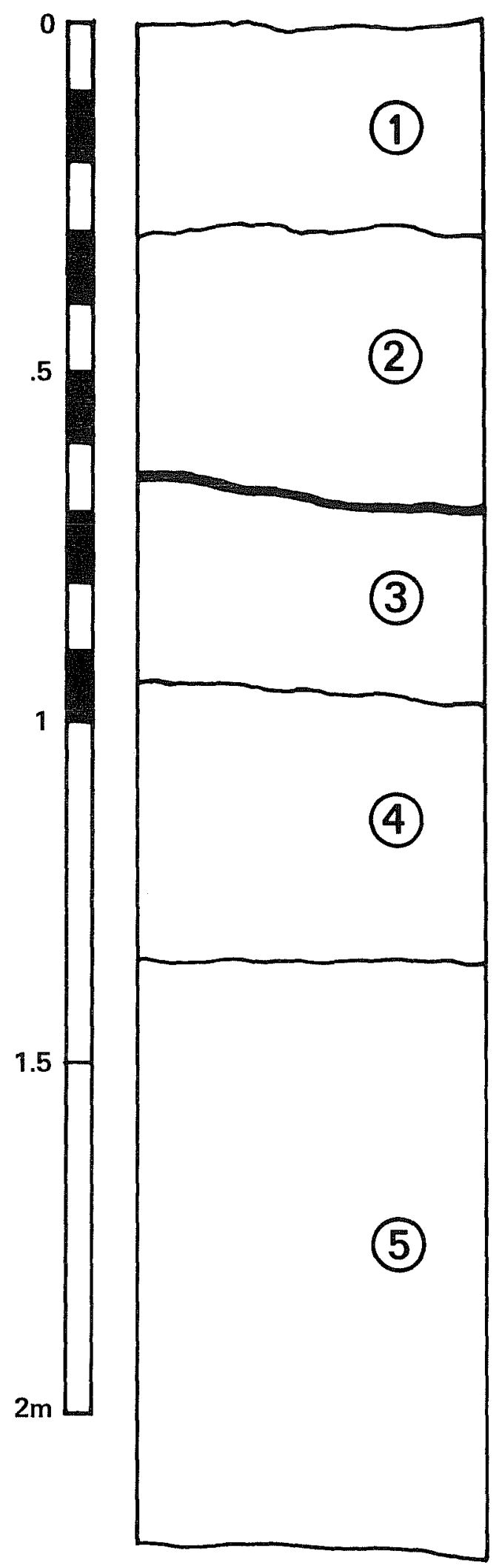

1 ground level-30 cm: Grayish brown (5YR3/2)

2 30-70* cm: Dark yellowish brown (10YR4/2)

The soils from ground level to $70 \mathrm{~cm}$ are part of the disturbed zone. Consolidation is moderately hard. The soil texture is silty clay. Caliche and mottled amounts of foreign soil (from no distinct zones) are mixed throughout the $30-70 \mathrm{~cm}$ level.

3 70-98 cm: Dusky yellowish brown (10YR2/2)

4 98-135 cm: Grayish brown (5YR3/2)

5 135-220 cm: Dark yellowish brown (10YR4/2)

The cultural deposit from site $41 \mathrm{BX} 1$ is found throughout this zone from $70 \mathrm{~cm}$ to an unknown depth. The sequence of deposition is identical or very similar to the undisturbed strata of all of the trenches. Soil color change is gradual and the soil is a homogeneous silt and clay mixture. The consolidation is moderately hard. In addition to prehistoric cultural debris (chert and burned rock), land snail shells are present.

This trench is part of site $41 \mathrm{BX} 1$; excavation Unit 1 was established on the west side of the trench. A discussion of site $41 \mathrm{BX} 1$ is in the following section of this report.

${ }^{*}$ Approximate depth.

Figure 7. Profile of Trench 5, 41 BX 1 . 
TRENCH 6

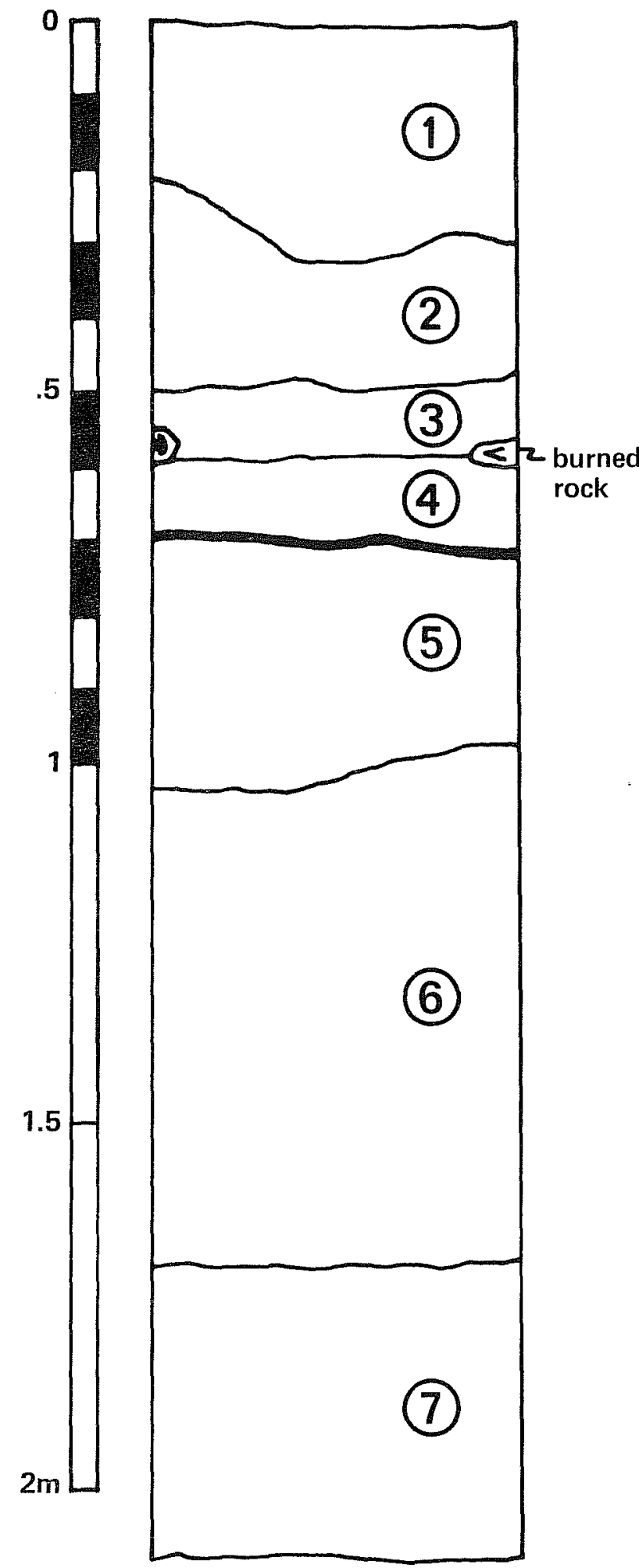

1 ground level-28* $\mathrm{cm}$ : Grayish brown (5YR3/2)

2 28-50 cm: Moderate yellowish brown (10YR5/4)

3 50-60 cm: Grayish orange (10YR7/4)

4 60-70 cm: Dark yellowish brown (10YR4/2)

The soils from ground level to $70 \mathrm{~cm}$ are of the disturbed zone. Consolidation ranges from moderately hard to loose. The $28-50 \mathrm{~cm}$ level has material from the top level and the $50-60 \mathrm{~cm}$ level mixed in it. The soils range from clay to a clay and silt mixture.

$570-103^{*} \mathrm{~cm}$ : Dusky yellowish brown (10YR2/2)

6 103-170 cm: Grayish brown (5YR3/2)

7 170-210 cm: Moderate yellowish brown (10YR5/4)

The undisturbed zone starts at $70 \mathrm{~cm}$ below the present ground surface. The color change is gradual and the soil is homogeneous in nature. Consolidation is moderately hard; soil texture is a silt and clay mixture.

A test column was excavated from $60 \mathrm{~cm}$ below the present ground surface to $140 \mathrm{~cm}$ below ground surface. No in situ archaeological remains were recovered.

${ }^{*}$ Approximate depth.

Figure 8. Profile of Trench 6 . 
TRENCH 9

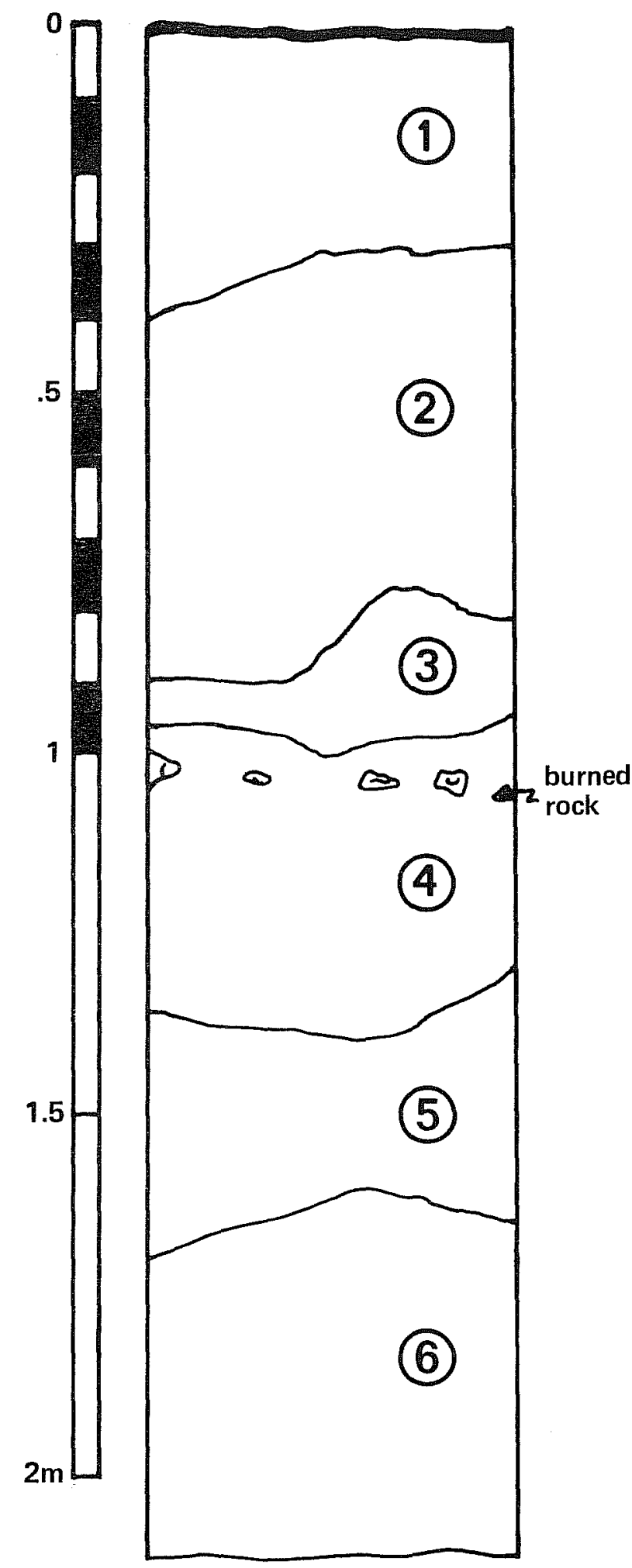

1 ground level-32* $\mathrm{cm}$ : Dusky brown (5YR2/2)

2 32-84* cm: Dusky yellowish brown (10YR2/2)

3 84-96* cm: Grayish brown (5YR3/2)

$496-135^{*} \mathrm{~cm}$ : Moderate yellowish brown (10YR5/4)

5 135-163* cm: Moderate brown (5YR4/4)

$6163-210 \mathrm{~cm}$ : Moderate yellowish brown (10YR5/4)

No obvious disturbed zone was present in this trench. The soil color change is very gradual from top to bottom. Consolidation is loose in the top $35 \mathrm{~cm}$ and gradually becomes a moderately hard consolidation at the bottom of the trench. The soil is homogeneous throughout. Texture is a silt and clay mixture. Bits of land snail shell and caliche pebbles are found throughout.

A column from the surface to $105 \mathrm{~cm}$ deep was tested. The results were negative as to the presence of cultural remains other than as a secondary deposit. There is a line of burned rock across the trench wall at roughly $100 \mathrm{~cm}$; however, this area proved to be sterile of culturally associated materials.

*Approximate depth. 
TRENCH 10

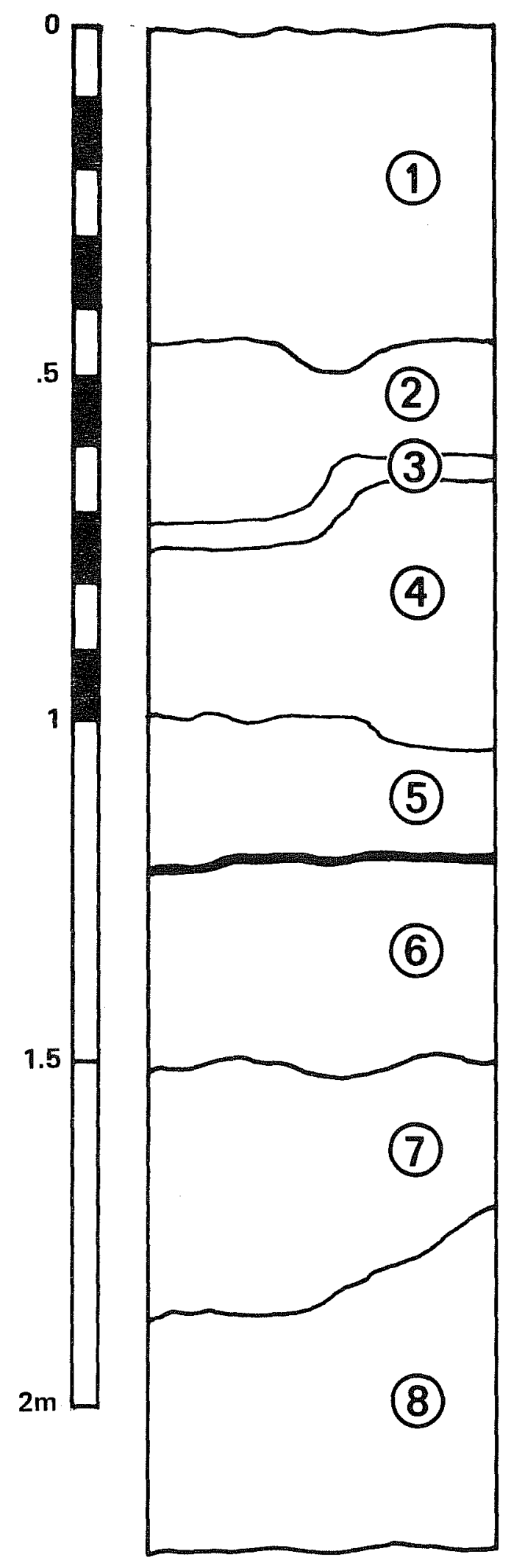

1 ground level-46 cm: Grayish brown (5YR3/2)

2 46-68* cm: Moderate yellowish brown (10YR5/4)

3 68-74* cm: Dark yellowish brown (10YR4/2)

$474-100 \mathrm{~cm}$ : Dark yellowish orange (10YR6/6)

5 100-120 cm: Moderate brown (5YR3/4)

The soils from ground level to $120 \mathrm{~cm}$ are of the disturbed zone. Consolidation from $74-100 \mathrm{~cm}$ is loose, but is moderately hard in the rest of the zone. All of the layers are clayey in texture with caliche pebbles and chunks mixed throughout.

$6120-150 * \mathrm{~cm}$ : Dusky yellowish brown (10YR2/2)

7 150-180* cm: Dusky brown (5YR2/2)

8 180-266* ${ }^{*} \mathrm{~cm}$ : Grayish brown (5YR3/2)

The undisturbed zone starts at $120 \mathrm{~cm}$ below the ground surface. The soil is homogeneous in nature and the color change is gradual. Soil texture is a silt and clay mixture. Consolidation is moderately hard. There are a few bits of land snail shell and caliche pebbles throughout.

A test column in this trench started at $95 \mathrm{~cm}$ below ground surface and extended to $185 \mathrm{~cm}$ below ground surface. The results were negative for any in situ archaeological remains.

* Approximate depth.

** The illustrated profile stops at $220 \mathrm{~cm}$. 
TRENCH 11

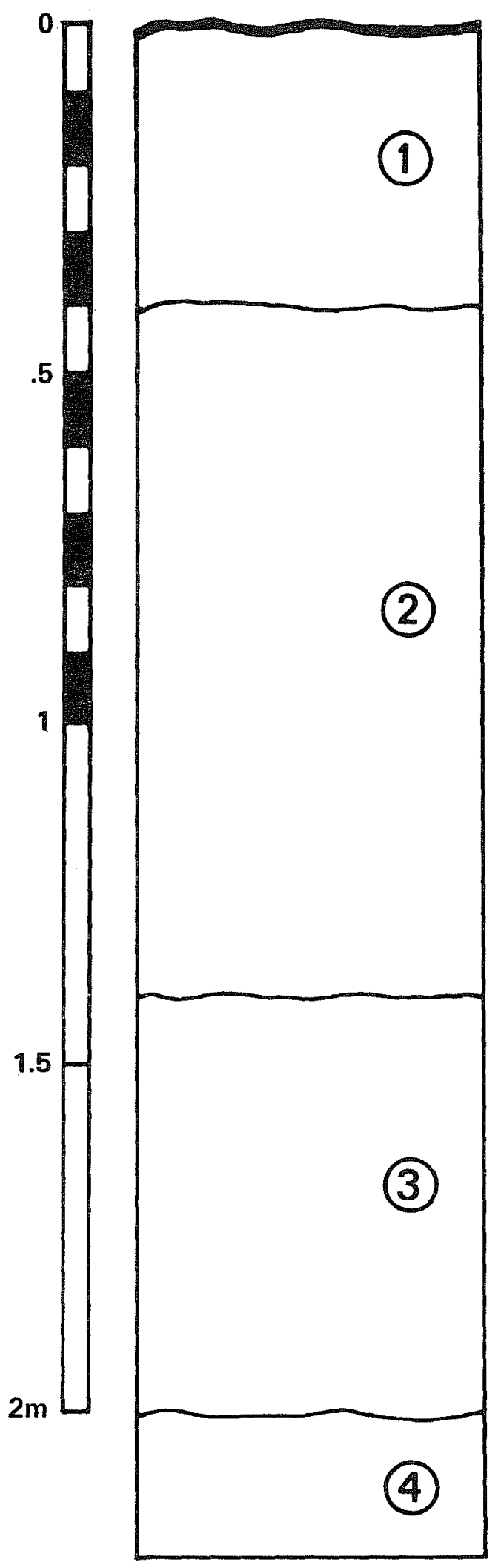

1 ground level-40 cm: Dusky yellowish brown (10YR2/2)

2 40-140 cm: Yellowish brown (10YR3/2)

3 140-200 cm: Dark yellowish brown (10YR4/2)

4 200-280* cm: Dark yellowish brown (10YR4/2) mixed with moderate yellowish brown (10YR5/4)

No soil disturbance is visible in this trench. Consolidation is moderately hard. Soil texture is a silt and clay mixture; soil color change is gradual. The soil is homogeneous to $200 \mathrm{~cm}$, where it changes to a mixed nature with limestone pebbles throughout.

*The illustrated profile stops at $220 \mathrm{~cm}$. 
TABLE 1. ARTIFACTS RECOVERED IN TESTS OF TRENCHES 3, 6, 9 AND 10

\begin{tabular}{|c|c|c|c|c|c|c|}
\hline & Flakes & $\begin{array}{c}\text { Burned } \\
\text { Rock }\end{array}$ & $\begin{array}{l}\text { Animal } \\
\text { Bone } \\
\text { Frags. }\end{array}$ & $\begin{array}{l}\text { Land } \\
\text { Snail } \\
\text { Shells } \\
\end{array}$ & $\begin{array}{c}\text { Historic } \\
\text { Items }\end{array}$ & Tota 1 \\
\hline $\begin{array}{l}\text { Trench } 3 \\
(50 \times 10 \times 15 \mathrm{~cm}) * \\
(90 \mathrm{~cm} \text { total })\end{array}$ & 8 & 2 & 1 & 1 & & 12 \\
\hline $\begin{array}{c}\text { Trench } 6 \\
(50 \times 10 \times 15 \mathrm{~cm}) \\
(90 \mathrm{~cm} \text { total })\end{array}$ & & & & 6 & & 6 \\
\hline $\begin{array}{c}\text { Trench } 9 \\
(50 \times 10 \times 15 \mathrm{~cm}) \\
(105 \mathrm{~cm} \text { total })\end{array}$ & 9 & 7 & & 16 & 5 & 37 \\
\hline $\begin{array}{c}\text { Trench } 10 \\
(50 \times 10 \times 15 \mathrm{~cm}) \\
(90 \mathrm{~cm} \text { tota } 1)\end{array}$ & 5 & 2 & 5 & 3 & & 15 \\
\hline Total & 22 & 11 & 6 & 26 & 5 & 70 \\
\hline
\end{tabular}




\section{SITE $41 \mathrm{BX} 1$}

As mentioned in the previous sections, the remains of prehistoric site $41 \mathrm{BX} 1$ were uncovered during trenching activities north of 01mos Dam. Trench 5 was cut into the buried site, and its location can be seen in Fig. 3.

\section{Site Description}

It is not possible to determine the original dimensions of site $41 \mathrm{BX} 1$ due to partial destruction and burial. Site 41 BX 1 , as seen by C. D. Orchard and J. H. McLellan prior to construction of the dam, is described in Orchard and Campbel1 (1954). In an area west of the site, they reported a bone bed containing faunal remains from bison, mastodon, horse, deer, peccary, rodents, birds, turtle and fish. The relationship of these faunal materials to the site is unknown since the bone bed has been thoroughly destroyed.

\section{Site Investigation}

While Trench 5 was being cleaned for profiling, two bifaces were found in the trench wall. One of the bifaces was identified as a Nolan dart point; the other is unclassifiable. A large charcoal sample was also recovered from the trench wall and is discussed in the Radiocarbon Dating section later in this report.

The soil in Trench 5 was disturbed from the ground surface to approximately $70 \mathrm{~cm}$ in depth. Prior to excavation, an area on the west side of the trench was cleared to the undisturbed soil zone by backhoe. A $1 \mathrm{~m}^{2}$ excavation unit was laid out next to the trench wall and excavated by shovel and trowel in $10 \mathrm{~cm}$ levels. All soil was screened through a 1/4-inch screen. The artifacts recovered from Unit 1 and from the backdirt of Trench 5 are listed in Table 2.

Unit 1 was excavated to determine whether any portion of site $41 \mathrm{BX} 1$ remained undisturbed. After excavating $40 \mathrm{~cm}$ into the undisturbed zone, it was evident that unaltered remains of site $41 \mathrm{BX} 1$ were still present in the area.

The most productive level from Unit 1 was the 20-30 $\mathrm{cm}$ level. The southern half of the level was carefully excavated; a Castroville dart point along with several flakes and animal bone fragments (possibly bison) were noted in situ; in the northern half of the level, which was excavated more quickly, only some animal bone and an associated Montell dart point were mapped in place (see Fig. 12). The trenches, excavation unit and site (Fig. 3) were surveyed and mapped utilizing a Brunton compass and a 30-meter tape, with the assistance of a San Antonio River Authority surveying crew. The measurements of the survey crew were converted into meters for archaeological use. The trenches were plotted as carefulty as possible in areas of thick brush cover. In Fig. 3, the elevations are in feet to correspond with USGS (United States Geological Survey) topographic maps and maps provided by the San Antonio River Authority. All other measurements are given in meters to correspond with general archaeological techniques. Surface surveying for artifacts was carried out wherever there were open areas; however, little of archaeological importance was noted. 

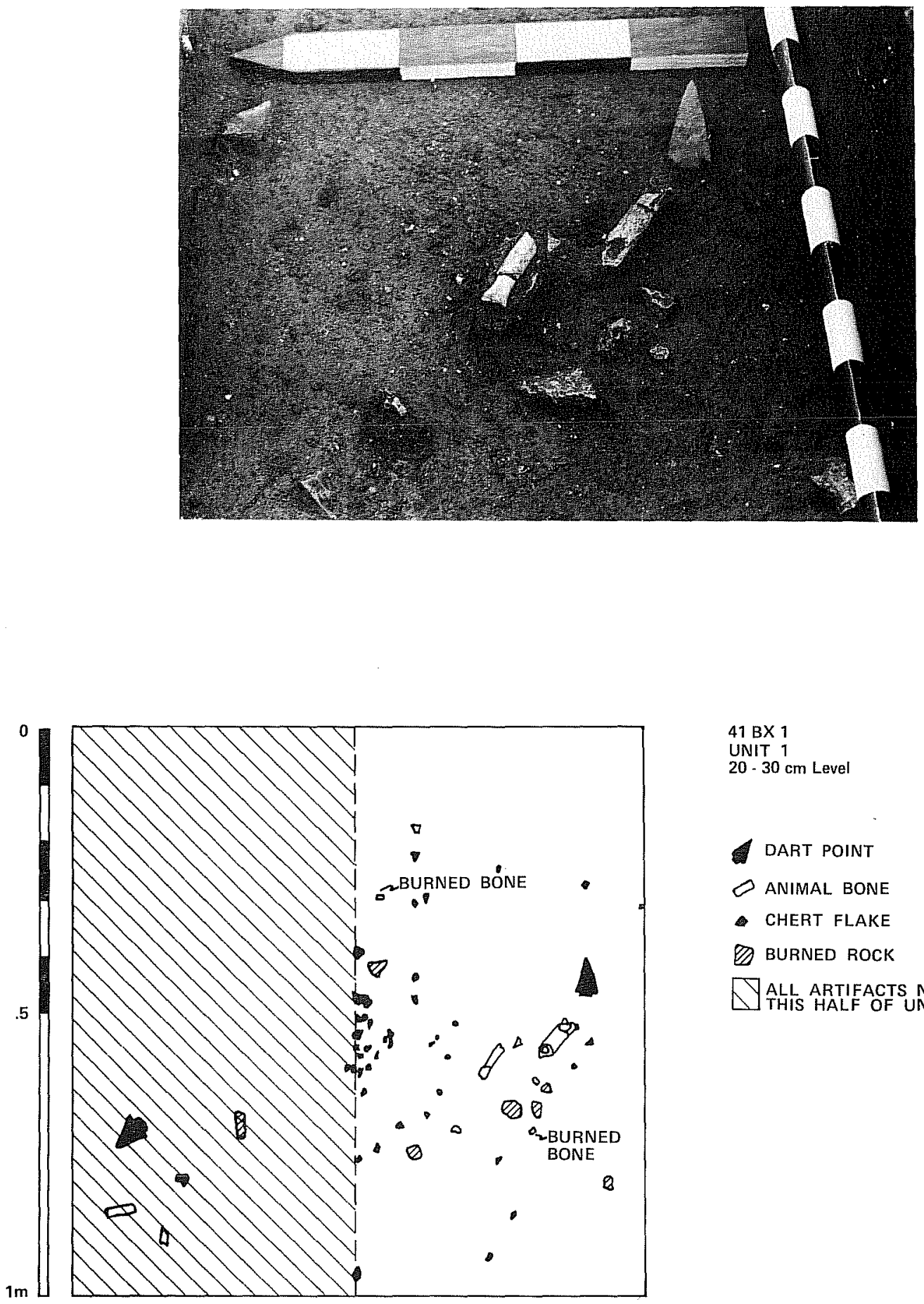

$41 \mathrm{BX} 1$

UNIT 1

$20 \cdot 30 \mathrm{~cm}$ Level

N $1 / 2$

S $1 / 2$

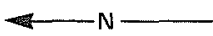

\section{DART POINT}

$\checkmark$ ANIMAL BONE

- chert flake

BURNED ROCK

DALL ARTIFACTS NOT MAPPED IN $\triangle$ THIS HALF OF UNIT

Figure 12. $41 \mathrm{BX} 1$, Unit 1, 20-30 cm Level. a, photograph showing the Castroville dart point, fiakes and animal bone in situ; b, map of the $30 \mathrm{~cm}$ floor of Unit 1 showing the Montell and Castroville dart points and associated artifacts. 


\section{Lithic Artifacts}

Very few lithic artifacts were recovered from the trenching operations and the surface survey. The majority of the lithic artifacts were from Unit 1 and are listed in Table 2.

The categories used for the description of chert artifacts include projectile points; bifaces; trimmed flakes; and primary, secondary and interion flakes. The descriptions of the lithic artifacts are basically the same as those found in the artifact description for site 41 BX 291 (Assad 1978), a site which is just south of 01mos Dam and probably closely related to site 41 BX 1.

The projectile points and bifaces categories include any whole or fragmented specimens exhibiting flake removal from both faces. The projectile points also show a refined degree of reduction and shaping (see Fig. 13,c-f).

The majority of the lithic debitage is separated into primary, secondary and interior flakes. The primary flakes are any specimens which have $90 \%$ or more dorsal cortex. The secondary flakes are specimens exhibiting less than $90 \%$ cortex. The interior flakes category includes specimens with no cortex present. No distinction of flakes based on platform or bulb of percussion was attempted.

The trimmed flakes category includes specimens which exhibit intentional edge shaping or retouch (see Fig. 13,a,b).

\section{Other Artifacts}

The artifacts recovered from the trenching activities, surface survey and the excavation unit are listed in Tables 1 and 2 . The majority of the artifacts were of chert and have been described previously.

The remaining types of artifacts are historic debris; animal bone; and mussel and land snail shells. The historic debris category is composed of items such as glass, wire nails and metal scrap of Anglo-European origin. The animal bone category is composed of fragmented pieces of bone from both large and smal1 animals; none of the bone is complete enough for positive identification. The mussel shell category includes fragmented, occasionally burned and unidentifiable freshwater mussel she11. The land snail shell category is composed of several genera of land snails. It includes Rabdotus sp., Mesodon sp., Polygyra $s p$. , Helisoma sp., Succinea sp., Practicollela sp., and one specimen of Rumina decollata. All of these types are native to central Texas with the exception of Rumina decollata, which is a European import.

Radiocarbon Dating

A large charcoal sample was collected from the west wall of Trench 5, just north of Unit 1. The sample was $90 \mathrm{~cm}$ below the undisturbed soil zone; a Nolan point and an unclassified dart point were noted $20 \mathrm{~cm}$ above the charcoal. 


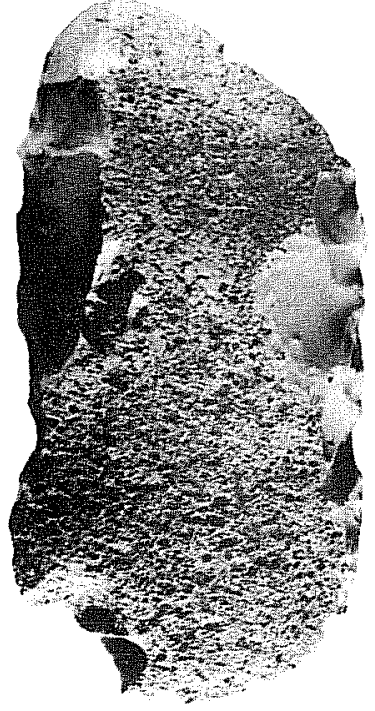

a

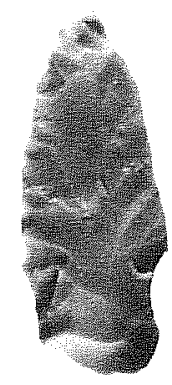

C

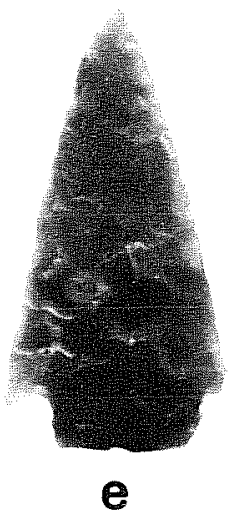

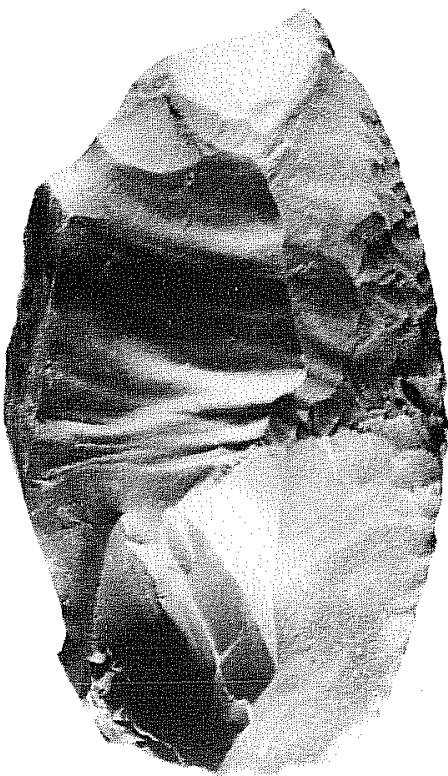

b
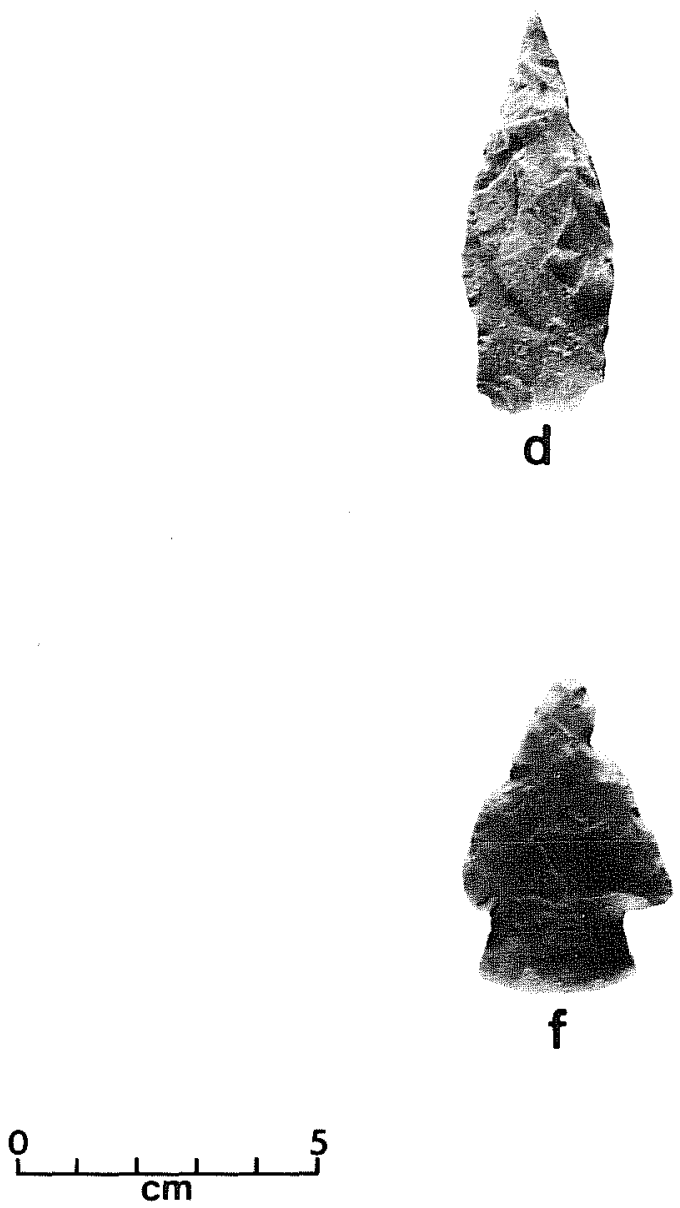

Figure 13. Artifacts from Unit 1 and the General Area. a,b, trimmed flakes; $c$, Nolan; d, unclassified; e, Montell; $f$, Castroville. 
TABLE 2. ARTIFACTS FOUND IN UNIT 1 AND TRENCH 5

\begin{tabular}{|c|c|c|c|c|c|c|}
\hline \multirow[b]{2}{*}{ Artifact } & \multicolumn{4}{|c|}{ UNIT 1} & \multirow{2}{*}{$\begin{array}{c}\text { TRENCH } 5 \\
\text { No } \\
\text { Location }\end{array}$} & \multirow[b]{2}{*}{ Total } \\
\hline & $\begin{array}{c}0-10 \\
\mathrm{~cm}\end{array}$ & $\begin{array}{c}10-20 \\
\mathrm{~cm}\end{array}$ & $\begin{array}{c}20-30 \\
\mathrm{~cm}\end{array}$ & $\begin{array}{c}30-40 \\
\mathrm{~cm}\end{array}$ & & \\
\hline $\begin{array}{c}\text { Projectile } \\
\text { points }\end{array}$ & & & 2 & & $2 \star$ & 4 \\
\hline Bifaces & & & 1 & 1 & & 2 \\
\hline $\begin{array}{l}\text { Trimmed } \\
\text { flakes }\end{array}$ & & & & 1 & 2 & 3 \\
\hline $\begin{array}{l}\text { Primary } \\
\text { flakes }\end{array}$ & & & & 2 & & 2 \\
\hline $\begin{array}{l}\text { Secondary } \\
\text { flakes }\end{array}$ & & 3 & 49 & 18 & & 70 \\
\hline $\begin{array}{r}\text { Interior } \\
\text { flakes }\end{array}$ & 4 & 19 & 196 & 47 & 4 & 270 \\
\hline $\begin{array}{l}\text { Animal bone } \\
\text { fragments }\end{array}$ & 1 & 10 & 81 & 23 & 1 & 116 \\
\hline $\begin{array}{l}\text { Land snail } \\
\text { shells }\end{array}$ & 59 & 64 & 57 & 37 & & 217 \\
\hline $\begin{array}{l}\text { Mussel } \\
\quad \text { fragments }\end{array}$ & & & 8 & & 2 & 10 \\
\hline Wire nails & & & & & 1 & 1 \\
\hline
\end{tabular}

*The provenience of these artifacts was $70 \mathrm{~cm}$ below the undisturbed soil level and in the west wall of Trench 5. 
The charcoal sample was processed by the Radiocarbon Laboratory, The University of Texas at Austin (sample number Tx-2927). The sample date is $3560 \pm 70$ B.P. or 1610 B.C. MASCA conversion tables (Ralph, Michael and Han 1973) indicate a date of 1920-1950 B.C.

The date for $T x-2927$ is one of the oldest radiocarbon dates produced in central Texas (see Gerstle, Kelly and Assad 1978). The sample is indirectly associated with a Nolan dart point, which is usually placed in the Early Archaic period. Sample Tx-2927 is below the Nolan point in stratigraphic depth; however, the radiocarbon date is within the Middle Archaic period as defined in the chronologies of Weir (1976), Prewitt (1974) and Gerstle, Kelly and Assad (1978).

Possibly the Nolan dart point type continued in use in central Texas later than previously noted.

\section{SUMMARY AND RECOMMENDATIONS}

Testing north of 01 mos Dam was undertaken to determine whether or not any significant historic or prehistoric archaeological resources were present in the 16 acres proposed as a borrow area for 01 mos Dam renovation. Portions of site 41 BX 1, which was largely destroyed by the 1920 dam construction, were found to be intact. No other significant archaeological resources were noted.

The precise boundaries of site $41 \mathrm{BX} 1$ could not be located by the testing. However, an area north of the dam and partially within the proposed borrow pit boundaries was marked off for protection; the protected area extends west to the right-of-way of Interstate Highway 37 (see Fig. 3).

On February 22, 1978, a survey party from the San Antonio River Authority met with the author at the borrow pit area to survey the protected area. The Chief Engineer, Mr. Dorian French, stipulated at that time that this area would be designated as inaccessible for borrowing activities. 


\section{REFERENCES CITED}

Assad, C. A.

1978 Archaeological Testing in an Area South of 01mos Dam, San Antonio, Texas. Center for Archaeological Research. The University of Texas at San Antonio, Archaeological Survey Report 54.

Brown, D.

1977 An Archaeological Survey of Proposed Areas for Alternate Roadways at 01mos Dam, San Antonio, Texas. Center for Archaeological Research. The University of Texas at San Antonio, Archaeological Survey Report 37.

Fawcett, W. B., Jr.

1972 The Prehistory of Bexar County: A Study of Previous Work in South Central Texas. Lower Plains Archaeological Society Bulletin 2:23-44.

Fox, A. A.

1975 An Archaeological Assessment of the Southern Portion of the 01mos Basin, Bexar County, Texas. Center for Archaeological Research, The University of Texas at San Antonio, Archaeological Survey Report 9.

Gerstle, A., T. C. Kelly and C. Assad

1978 The Fort Sam Houston Project: An Archaeological Assessment. Center for Archaeological Research. The University of Texas at San Antonio, Archaeological Survey Report 40.

Luke, C.

1974 Archeological Investigation Along the Route of U.S. 281, from Mulberry Avenue to Tuxedo Avenue in San Antonio. Texas Highway Department manuscript.

Metcalf \& Eddy (Consulting Engineers)

1920 Flood Prevention in San Antonio, Texas. Report to City of San Antonio upon Flood Prevention. Manuscript at San Antonio River Authority office.

Orchard, C. D. and T. N. Campbell

1954 Evidence of Early Man from the Vicinity of San Antonio, Texas. Texas Journal of Science 6(4):454-465.

1960 Southwestern Pottery from Sites in the Vicinity of San Antonio, Texas. Texas Archeology 4(2):7-8. 
Pioneer Flour Mills

1951 01mos Dam Construction. Photograph from 100th Anniversary Pioneer Flour Mills, San Antonio, Texas 1851-1951:page 63. The Naylor Company, San Antonio, Texas.

Prewitt, E. R.

1974 Archeological Investigations at the Loeve-Fox Site, Williamson County, Texas. Texas Archeological Survey. The university of Texas at Austin, Research Report 49.

Ralph, E. K., H. N. Michael and M. C. Han

1973 Radiocarbon Dates and Reality. Applied Science Center for Archaeology, MASCA Newsletter 9(1):1-20.

San Antonio River Authority

1970 The San Antonio Channel Improvement Project. An Intergovernmental Effort to Reduce Flooding in the San Antonio Metropolitan Area. A Status Report.

Taylor, F. B., R. B. Hailey and D. L. Richmond

1966 Soil Survey of Bexar County, Texas. U.S. Department of Agriculture, Soil Conservation Service, Series 1962:12.

Weir, F. A.

1976 The Central Texas Archaic Reconsidered. In: The Texas Archaic: A Symposium. T. R. Hester, ed. Center for Archaeological Research. The University of Texas at San Antonio, Special Report 2:60-66.

Woolford, S. W.

1935 Types of Archaeological Sites in Bexar County, Texas. Witte Museum. Archaeological Bulletin 4. 


\section{APPENDIX}

While 01 mos Dam was under construction in the 1920s, several people collected artifacts from the backdirt piles and exposed sections of site $41 \mathrm{BX} 1$. Mr. Brentano C. Harnish has allowed a sampling of his artifact collection from $41 \mathrm{BX} 1$ to be illustrated here (see Figs. 14 and 15).

One of the specimens, a Golondrina projectile point (Fig. 14,g), is considered to be a common form of Paleo-Indian projectile point in south Texas (Hester 1977). This type of Paleo-Indian point has also been found several miles from 01 mos Basin at site 41 BX 229 on St. Mary's Hall property (Hester 1978). Hester (ibid.) dates the Golondrina form to 7000 B.C., based on radiocarbon dates from Baker Cave.

Another 41 BX 1 specimen, a Carrizo dart point (Fig. 14,e), probably dates to the Archafc Period and is found in central, southern and southwest Texas (House and Hester 1967).

The remaining artifacts illustrated include four dart points, [three of which are possible Castroville points (Fig. 14,f; Fig. 15,a,b) and one unclassified point (Fig. 14,d)]; two crude bifaces (Fig. 15,c,d); a perforator (Fig. 14,h); and three finely-worked bifaces (Fig. 14,a-C), which may have functioned as knives. One biface specimen (Fig. $14, \mathrm{~b}$ ) is oval in outline with parallel flaking; another (Fig. 14,C) is triangular and not as finely worked; and the last specimen (Fig. 14,a) is a curved and sickle-like biface, shaped from extensive reworking and use.

REFERENCES CITED

Hester, T. R.

1977 The Current Status of Paleo-Indian Studies in Southern Texas and Northeastern Mexico. In: "Paleoindian Lifeways, "Eileen Johnson, Editor. The Museum Journal, XVII, West Texas Museum Association, Texas Tech University, Lubbock.

1978 Early Human Occupations in South Central and Southwestern Texas: Preliminary Papers on the Baker Cave and St. Mary's Hall Sites. Center for Archaeological Research, The University of Texas at San Antonio.

House, J. W. and T. R. Hester

1967 The Carrizo Type. Texas Archeology, The Newsletter of the Texas Archeological Society 11(3):8-9. 

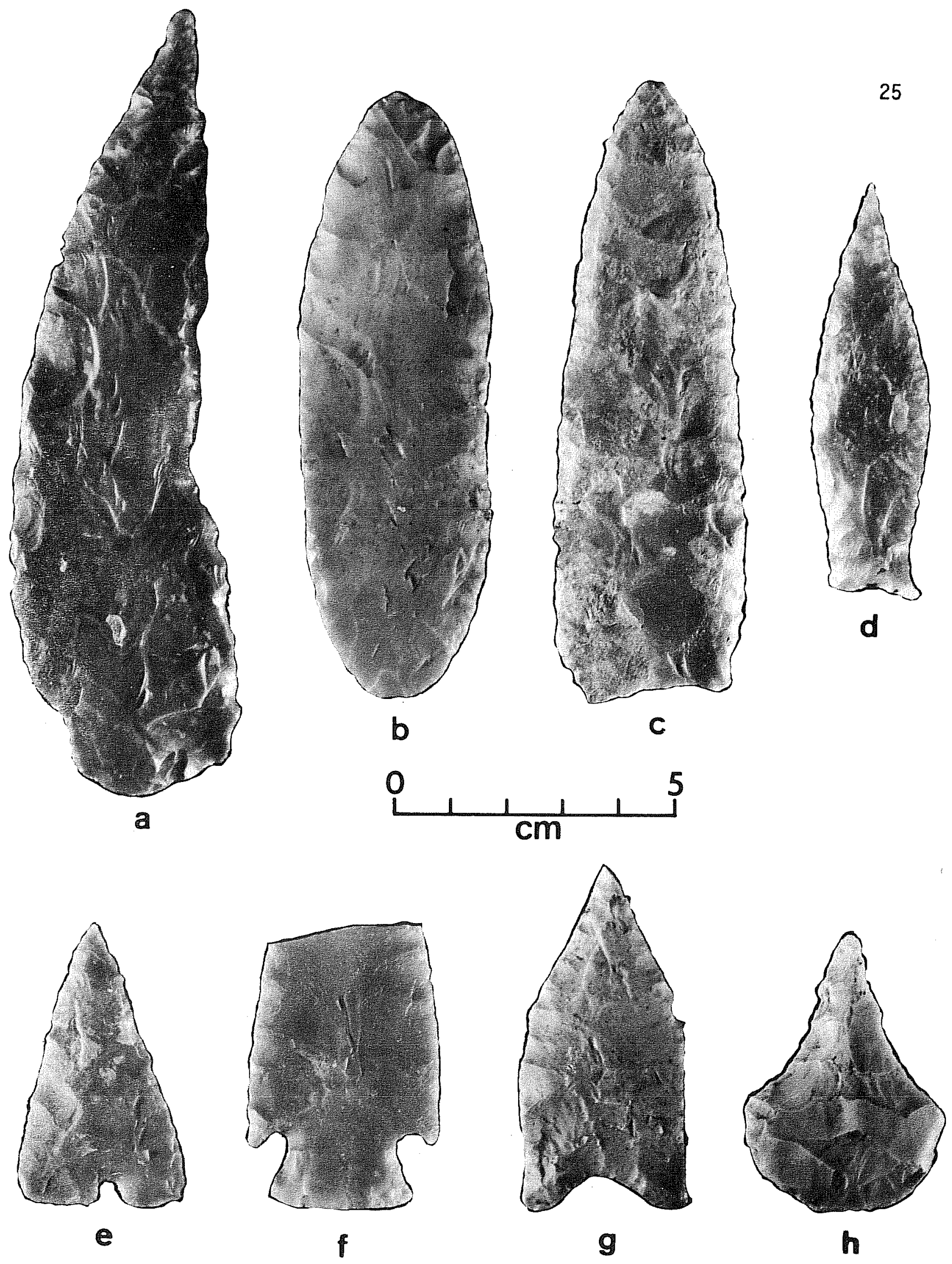

Figure 14. Artifacts from $41 \mathrm{BX} 1$. a-c, bifaces; d, unclassified dart point; e, Carrizo; f, Castroville; $g$, Golondrina; $h$, perforator. 


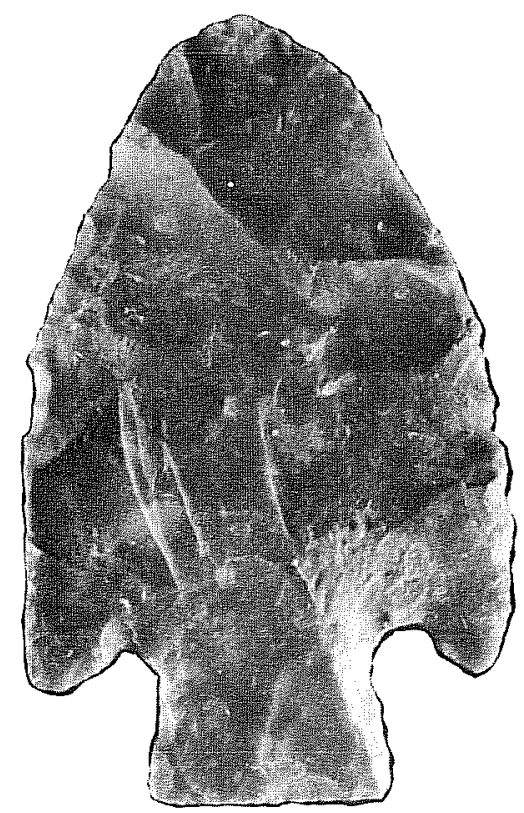

a

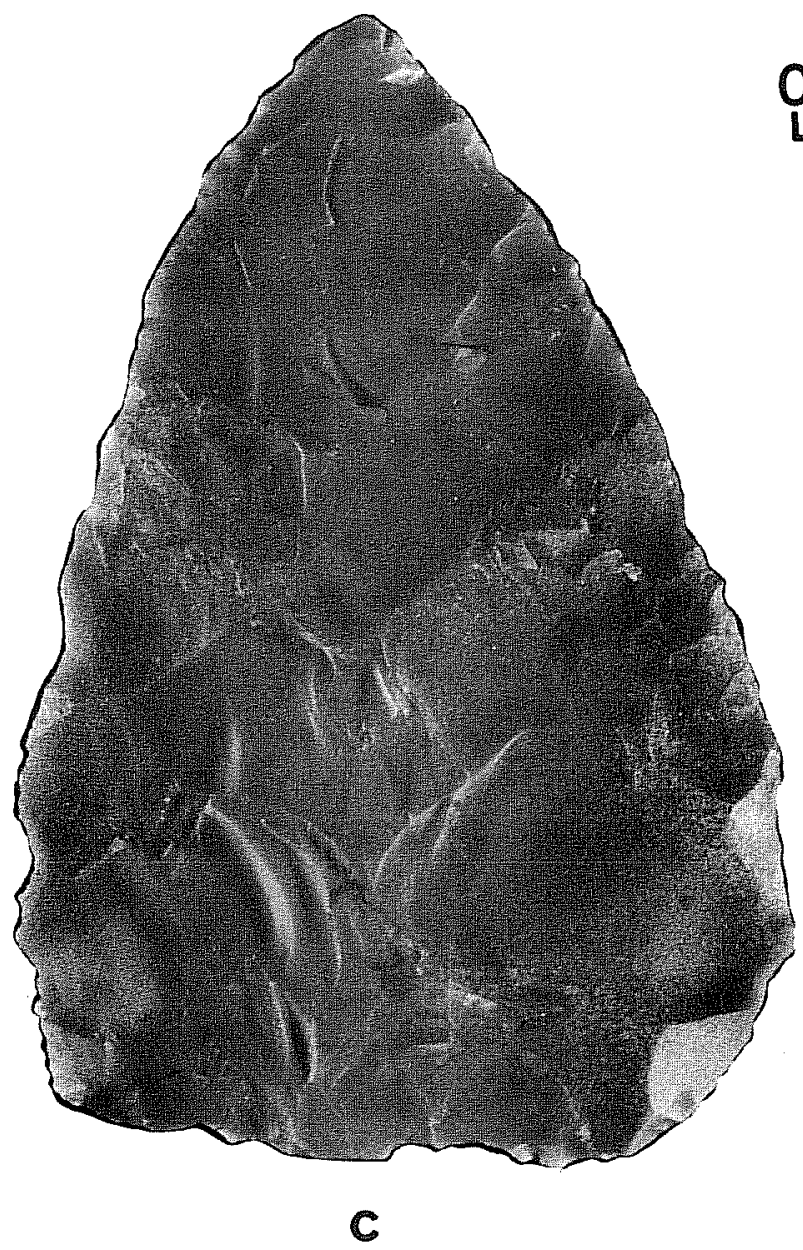

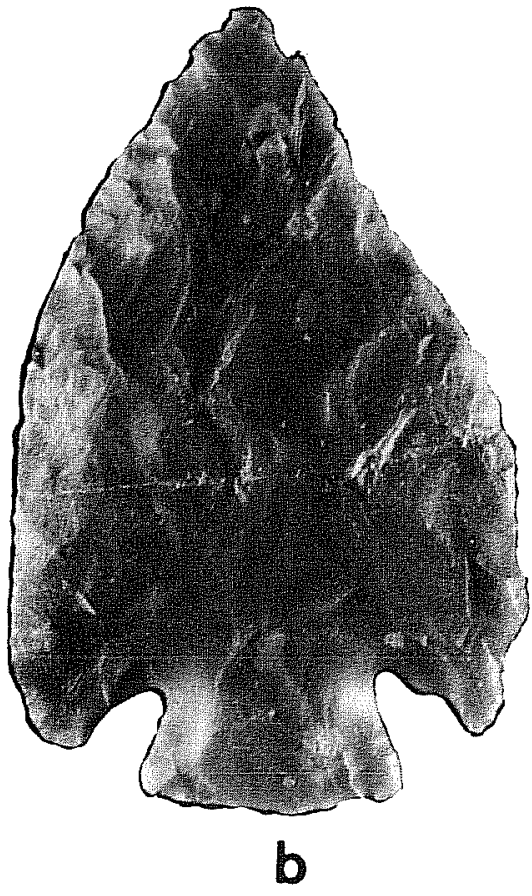
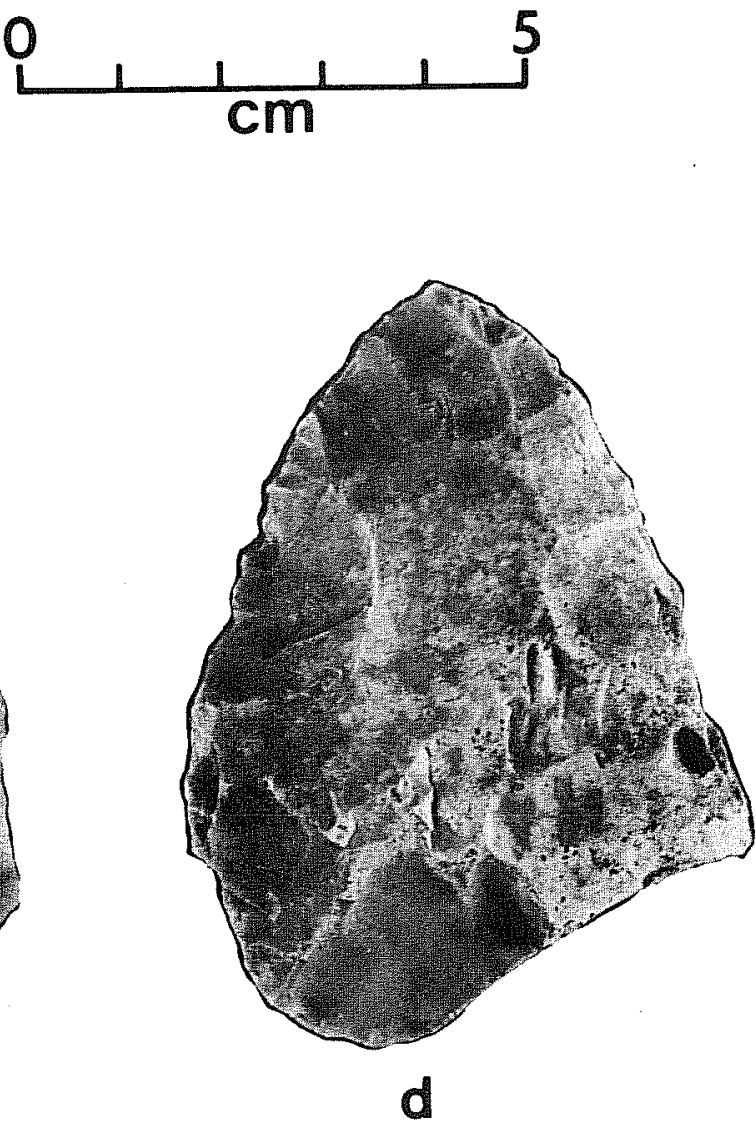

Figure 15. Artifacts from 41 BX 1. a,b, Castroville; $c, d$, crude bifaces. 